\title{
SUBSTITUSI BEKATUL PADA PEMBUATAN BISKUIT TERHADAP PENINGKATAN KADAR SERAT SEBAGAI JAJANAN TINGGI SERAT
}

\author{
Hendrayati $^{1}$, Manjilala $^{1}$, Feni Islamiati ${ }^{2}$ \\ ${ }^{1}$ Jurusan Gizi, Politeknik Kesehatan Kemenkes Makassar \\ ${ }^{2}$ Alumni Jurusan Gizi, Politeknik Kesehatan Kemenkes Makassar \\ *) E-mail hendrayati@poltekkes-mks.ac.id
}

\begin{abstract}
Obesity in Indonesia is still a serious health problem. The accelerating progress of The Times has resulted in unhealthy diet changes. One of the most common habits of ingesting high fat but low fiber. The bran is one of the high-fiber food items that can be used as a high fiber alternative food. One of a food products that can be served as food or a high fiber snack that is a biscuit in substitution. The study was intended to determine the effect of the substitution of the paste in the making of biscuits in the increase in fiber levels as high fiber snacks. Research design is an experiment with the posstest only design group. The fiber analysis uses the crude fiber method to measure the fiber level of the biscuit with a concentration of $0 \%$, $10 \%, 20 \%$, and 30\%. Studies indicate that the higher the concentration of these added amounts to the higher the concentration of the fibers. Crackers with the highest fiber substitution 30\% concentrations with a rate of $28.37 \%$. Bran biscuits could be recommended for snacks or high fiber snacks. It is recommended to develop food products with beshed food and analyze other nutrients.
\end{abstract}

Keywords : analyst, biscuit, bran, fiber

\section{PENDAHULUAN}

Kemajuan zaman yang semakin pesat telah berdampak pada perubahan gaya hidup masyarakat Indonesia, mulai dari pola makan yang tidak sehat sampai kurangnya aktivitas fisik. Salah satunya kebiasaan mengonsumsi cemilan yang tinggi lemak dan rendah serat namun tidak diimbangi dengan aktivitas yang cukup. Kebiasaan ini terutama terjadi pada masyarakat yang tinggal di perkotaan, mereka lebih memilih untuk mengonsumsi makanan yang siap saji dan praktis, seperti makanan cepat saji yang sebagian besar merupakan pangan hewani. Seringnya mengonsumsi pangan hewani yang tidak diimbangi dengan pangan nabati membuat asupan serat seseorang menjadi rendah (Kandou, 2009).
Dewasa ini kurangnya konsumsi serat menjadi faktor yang dapat menyebabkan terjadinya obesitas. Salah satu kelompok umur yang beresiko terjadinya obesitas adalah usia remaja. Berdasarkan Riskesdas prevalensi obesitas pada remaja Indonesia pada tahun 2013 mencapai $14,8 \%$ dan mengalami peningkatan pada tahun 2018 sebesar 21,8\%. Dari 34 provinsi, Sulawesi Selatan menempati urutan ke-26 tertinggi remaja obesitas (Riskesdas, 2018)

Berdasarkan hasil penelitian Kurniawati (2010) menunjukkan bahwa kadar serat cookies cenderung meningkat. Semakin besar subsitusi bekatul dan tepung ampas wortel maka semakin besar kadar serat cookies. Semakin besar persentase penambahan bekatul beras merah, kadar protein, lemak, karbohidrat, serat dan 
aktivitas antioksidan sosis tempe semakin meningkat (Kusumastuti \& Ayustaningwarno, 2013).

Berdasarkan data Badan Pusat Statistik (BPS), produksi padi di Indonesia tahun 2018 sebesar 56,54 juta ton gabah kering giling (GKG) dengan $10 \%$ dari total produksi padi dapat menghasilkan bekatul, maka diperkirakan akan dapat menghasilkan 5,65 juta ton bekatul (BPS, 2018).

\section{METODE}

\section{Desain, tempat dan waktu}

Penelitian ini merupakan eksperimen dengan menggunakan rancangan posttest only goup desain. Penelitian ini dilaksanakan di Laboratorium Teknologi Pangan Jurusan Gizi Politeknik Kesehatan Makassar dan Laboratorium SMK-SMTI Makassar pada bulan Februari sampai April 2019.

\section{Bahan dan alat}

Bahan yang digunakan dalam penelitian ini adalah tepung terigu, bekatul, kuning telur, gula halus, margarine, lemak nabati (room butter), tepung maizena, susu bubuk, baking powder, vanili dan garam. Alat yang digunakan adalah kompor, oven, loyang, wajan, sutil, mixer, cetakan biskuit, gelas ukur, timbangan, baskom dan sendok.

\section{Langkah-langkah penelitian}

Pembuatan biskuit bekatul dilakukan di Laboratorium Teknologi Pangan Jurusan Gizi Poltekkes Kemenkes Makassar. Analisis kandungan serat pada biskuit bekatul dilakukan di Laboratorium SMKSMTI Makassar.

\section{Pengolahan dan analisis data}

Data hasil uji laboratorium kandungan serat pada biskuit bekatul diolah menggunakan program komputer yaitu Microsoft Excel dan ditabulasi dalam bentuk tabel kemudian dianalis menggunakan Statistical Product and Service Solution (SPSS) yaitu uji Kruskal Wallis. Data yang telah dianalisis disajikan dalam bentuk tabel dan gafik disertai dengan penjelasan dalam bentuk narasi .

\section{HASIL}

Bekatul yang digunakan adalah bekatul beras putih yang diproleh pada proses penyosohan kedua dari penggilingan beras. Bekatul tersebut dilakukan pengayakan yang kemudian dilakukan penyangaian sekitar \pm 15 menit sampai berubah warna menjadi agak kecoklatan guna untuk menghilangkan mikroorganisme dan memperhambat terjadinya kerusakan pada bekatul.

Tabel 01

Hasil Uji Serat Biskuit Substitusi Bekatul

\begin{tabular}{cccc}
\hline \hline Konsentrasi & Kadar Serat & Satuan & $\mathrm{p}$ \\
\hline $0 \%$ & 21,70 & $\mathrm{~g}$ & \\
$10 \%$ & 22,07 & $\mathrm{~g}$ & \\
$20 \%$ & 23,59 & $\mathrm{~g}$ & 0,083 \\
$30 \%$ & 28,78 & $\mathrm{~g}$ & \\
\hline
\end{tabular}

Proses pembuatan biskuit dengan substitusi bekatul ditambahkan setelah semua bahan tercampur rata. Biskuit dipanggang dalam oven dengan suhu \pm $150^{\circ} \mathrm{C}$ dengan waktu selama 15 menit. Perbandingan atau jumlah bekatul yang ditambahkan yaitu dengan konsentrasi $10 \%$ (25 gam), 20\% (50 gam) dan 30\% (75 gam) dari 250 gam tepung terigu. Biskuit bekatul yang dihasilkan berwarna coklat kekuningan, aroma sedikit khas bekatul, tekstur renyah, rasa manis. Biskuit yang dihasilkan memiliki berat $10 \mathrm{~g} / \mathrm{keping}$ biskuit.

Analisis kadar serat biskuit substitusi bekatul dilakukan sebanyak dua kali (duplo) dengan menggunakan metode crude fiber dan hasil dirata-ratakan untuk mendapatkan nilai kadar serat pada biskuit dengan substitusi bekatul, kemudian membandingkan nilai kadar serat pada setiap konsentrasi dengan biskuit bekatul tanpa substitusi bekatul dalam biskuit untuk 
melihat peningkatan kadar serat pada biskuit. Nilai rata-rata biskuit substitusi bekatul dengan konsentrasi $0 \%$ yaitu 21.70 g. Biskuit substitusi bekatul dengan konsentrasi $10 \%$ yaitu 22.07 g. Biskuit substitusi bekatul dengan konsentrasi $20 \%$ yaitu 23.59 g. Biskuit substitusi bekatul $30 \%$ yaitu $28.78 \mathrm{~g}$.

Data hasil uji laboratorium kandungan serat dianalisis menggunakan uji Kruskal Wallis dengan derajat kepercayaan $95 \%$, diperoleh $\mathrm{p}>0.05$ yaitu $\mathrm{p}=0.083$ yang berarti bahwa tidak ada perbedaan yang signifikan dari hasil analisis tersebut.

\section{PEMBAHASAN}

Penelitian ini terdapat empat konsentrasi biskuit yang berbeda-beda yaitu biskuit tanpa penambahan bekatul, biskuit penambahan bekatul konsentrasi $10 \%$, konsentrasi $20 \%$ dan konsentrasi $30 \%$. Biskuit tanpa penambahan bekatul memiliki rerata kandungan serat sebesar 21,70 g. Pada biskuit substitusi bekatul dengan konsentrasi $10 \%$ memiliki rerata kandungan serat sebesar 22,07 g dan memiliki peningkatan kadar serat sebesar 0,37 g. Biskuit dengan konsentrasi $20 \%$ memiliki kandungan kadar serat sebesar 23,59 g dan memiliki peningkatan kadar serat 1,89 g. Biskuit dengan konsentrasi $30 \%$ memiliki kandungan serat sebesar 28,78 g dan memiliki peningkatan kadar serat sebesar 7,08 g dengan berat biskuit yaitu $10 \mathrm{~g} /$ keping. semakin tinggi penambahan bekatul pada biskuit maka semakin tinggi kadar serat pada biskuit. Hal ini disebabkan karena bekatul mempunyai kadar serat 2,3-3,2 g/100 g bekatul (Astawan, 2009).

Penelitian ini sejalan dengan penelitian yang dilakukan oleh Susanto (2011) yang membuat produk selai kacang dengan variasi jenis dan formulasi substitusi bekatul menghasilkan kadar serat kasar pada selai kacang meningkat seiring dengan meningkatnya substitusi bekatul.
Penelitian yang dilakukan Kurniawati (2010) menunjukkan bahwa kadar serat cookies cenderung meningkat. Semakin besar substitusi dengan bekatul dan tepung ampas wortel maka semakin besar kadar serat cookies. Biskuit substitusi bekatul mengalami peningkatan kadar serat dengan semakin tingginya konsentrasi bekatul yang ditambahkan dalam biskuit. Hal ini menunjukkan bahwa biskuit yang memiliki kandungan serat tertinggi yaitu konsentrasi $30 \%$. Semakin tinggi konsentrasi penambahan bekatul maka biskuit semakin keras disebabkan karena serat pada bekatul mengandung selulosa yang merupakan struktur keras dinding sel tanaman (Andarwulan et al., 2011).

Jika mengacu pada tabel Angka Kecukupan Gizi (AKG) tahun 2013 tentang kebutuhan serat remaja sebesar 20-38 g/hari, maka biskuit substitusi bekatul dapat dikonsumsi sebanyak 9 - 17 keping/hari untuk memenuhi kebutuhan serat dalam sehari. Dalam hal ini membuktikan bahwa bekatul merupakan bahan pangan yang kaya akan serat.

Konsumsi serat yang cukup sesuai kebutuhan mempunyai fungsi bagi kesehatan. Konsumsi serat juga dapat menurunkan atau mempertahankan berat badan sehingga tidak terjadi obesitas. Semakin tinggi asupan serat maka semakin rendah lingkar pinggang, tekanan darah, kadar kolesterol total, trigliserida, kolesterol LDL, kolesterol HDL dan kadar glukosa darah puasa (Santawati, 2010).

\section{KESIMPULAN}

Biskuit substitusi bekatul semakin
tinggi konsentrasi bekatul yang
ditambahkan maka semakin tinggi kadar
serat yang terdapat dalam biskuit dengan
berat biskuit $10 \mathrm{~g} / \mathrm{keping}$. Kadar serat pada
masing-masing biskuit substitusi bekatul
dengan konsentrasi $0 \%$ yaitu $21,70 \mathrm{~g}$,
konsentrasi $10 \%$ yaitu $22,07 \mathrm{~g}$, konsentrasi
$20 \%$ yaitu $23,59 \mathrm{~g}$, konsentrasi $30 \%$ yaitu
$28,78 \mathrm{~g}$ dalam $100 \mathrm{~g}$ biskuit substitusi


bekatul. Biskuit subsitusi bekatul yang memiliki kadar serat tertinggi yaitu biskuit dengan konsentrasi $30 \%$.

\section{SARAN}

Bagi peneliti selanjutnya diharapkan dapat melakukan pengujian laboratorium dengan zat gizi lain dan dapat mengembang produk pangan dengan bahan pangan bekatul serta diharapkan mampu melakukan pengujian biskuit kepada remaja obesitas untuk melihat peningkatan asupan serat serta monitoring status gizi selama mengonsumsi biskuit.

\section{DAFTAR PUSTAKA}

Andarwulan, N., Kusnandar, F. \& Herawati, D. (2011). Analisis Pangan. Penerbit Dian Rakyat. Jakarta.

Astawan M. (2009). Sehat dengan Hidangan Kacang dan Biji-bijian. Jakarta; Penebar Swadaya.

Badan Pusat Statistik. (2018). Produksi Padi Tahun 2018.

Kandou. (2009). Makanan Etnik Minahasa dan Kejadian Penyakit Jantung Koroner. Jurnal Kesehatan Masyarakat. Vol 4, No. 1. Hal 4248.

Kurniawati, L. (2010). Pemanfaatan Bekatul Dan Ampas Wortel (Daucus Carota) Dalam Pembuatan Cookies. Jurnal Teknologi Hasil Pertanian, Vol. III, No.2, Agustus 2010.

Kusumastuti, K. \& Ayustaningwarno,F. (2013). Pengaruh Penambahan Bekatul Beras Merah Terhadap Kandungan Gizi, Aktivitas Antioksidan dan Kesukaan Sosis Tempe. Jurnal of Nutrition College, Volume 2, Nomor 1, Tahun 2013, Hal 27-34.

Riset Kesehatan Dasar (RISKESDAS). (2018). Jakarta: Badan Penelitian dan Pengembangan Kesehatan, Departemen Kesehatan, Republik Indonesia.
Santawati, F. (2010). Hubungan asupan serat dengan beberapa faktor resiko penyakit kardiovaskuler. Artikel Penelitian. Fakultas Kedokteran Universitas Diponegoro, Semarang.

Susanto, D. (2011). Potensi Bekatul Sebagai Sumber Antioksidan Dalam Produk Selai Kacang. Artikel Penelitian. Fakultas Kedokteran Universitas Diponegoro, Semarang. 